\title{
Slower and Cooler in the United States
}

by our Washington Correspondent

IN the next few months, nearly every American is going to be brought face to face with the energy crisis, for it is now clear that there may be rationing of petrol and heating oil, closing of some schools and offices, shorter working hours and even a few cold homes. Apart from the inconvenience and upset that these situations will cause, their overall effect will be to force Americans to cut back on their use of energy-not just this winter, but permanently. And that will require some rather fundamental changes in a society that has been mindlessly consuming energy at a staggering rate.

Last week, President Nixon went on television to warn the country of the gravity of energy shortages that are likely to develop in the United States this winter, and to outline emergency measures that his Administration wants to take to deal with the situation. The reaction has been startling. Newspapers have been filled with little else-for a time the energy crisis even eclipsed Watergate as the focus of national attention-state governors have been announcing measures to curtail consumption of energy in their territories, and a few people have turned down their central heating. On Capitol Hill, committees have been stung into action and have passed legislation to give the President sweeping powers to force a reduction in the use of energy throughout the country. And the Stock Exchange has seen the biggest drop in share prices in 11 years.

The root cause of the impending shortages is that the growth in energy consumption in the United States has for years been outstripping the growth in supply. But the situation has been blown into crisis proportions by the embargo that Arab countries have placed on their oil exports to the United States, an action which will strip 2 million barrels of oil a day off the supply. The Arab cutoff, together with shortages that were developing in any case, could result in oil supplies falling short of demand by $17 \%$ when winter finally arrives. The problem, however, is that the shortages will not be evenly distributed, for it is predicted that the gap could reach an incredible $40 \%$ in the Northeast, an area which relies heavily on imported oil.

That is the prospect which caused President Nixon last week to deliver his third energy message to the American public so far this year. Unlike the pre- vious messages, which have been concerned chiefly with increasing energy supply, and which have paid only scant lip service to the need for reducing demand, the latest effort was concerned almost exclusively with emergency measures that must be taken to decrease consumption of energy. The message came too late, and it was only forced by what President Nixon referred to as "the most acute shortages of energy since World War II", but nevertheless it represents a fundamental break with the Administration's previous attempts to deal with the energy crisis.

What Nixon is asking, in short, is for Congress to give him broad emergency powers to force people to curtail their energy appetites, and he is also appealing to the American public to act voluntarily.

Among the measures outlined in his message are the following:

- The Administration wants the power to order neon lights and ornamental lighting to be turned off, a measure which would have the welcome effect of getting rid of some of the neon nightmares that encircle so many American cities.

- President Nixon is requesting authority to force shops to close early, to require speed limits to be lowered on all roads, and to impose emergency taxes on consumption of natural gas and on excessive uses of electricity.

- He wants Congress to pass a bill authorising the use of daylight savings time (the equivalent of British Summer Time) throughout the year-a measure which could save up to $3 \%$ in electricity consumption, particularly in the northern areas which are most affected by lack of fuel.

- Finally, he is asking for broad authority to allow power plants to be exempt from air pollution regulations, so that they can burn coal and oil containing relatively large quantities of sulphur.

Those measures all require Congressional approval, but the Administration already has powers to force other changes, and it is using them. Regulations are being drawn up to prevent factories and power stations from switching from coal to oil, and the Administration is also putting pressure on electricity producers to convert power plants from oil to coal. The White House says that 46 plants can be converted within two months, at a saving of nearly half a million barrels of oil a day. The number of commercial jet flights in the United States has been reduced by the
Federal Aviation Administration, and Nixon decreed that thermostats be turned down in federal buildings. $\mathrm{He}$ also appealed for central heating to be turned down in private homes, for cars to be driven at speeds less than 50 m.p.h., for more use of mass transit, and for more car pooling.

Scarcely were the words of exhortation out of President Nixon's mouth when Congress was galvanised into unprecedented action. Senator Henry M. Jackson, chairman of the Senate Interior Committee and the most influential member of the Senate on energy matters, rammed a bill through his committee, after a day of hearings in a cool committee room, and the House Commerce Committee also expects to get a bill passed this week. Thus Congress is likely, by the end of next week, to have given President Nixon most of the powers he requested.

The emergency measures proposed by Nixon seem tougher, at least if implemented, than the British government's proposals announced on Tuesday in the face of a crisis exacerbated by a miners' overtime ban.

But will they be sufficient to cope with the situation? By all accounts they will not, and the Administration is developing plans to ration petrol and fuel oil if the need arises. For one thing, the measures announced last week will rely heavily on public cooperation and voluntary compliance, and for another, some of them have come too late to be effective. For example, the proposal to convert power plants from oil to coal--a fuel which the United States has in abundance-is likely to be stymied by the fact that coal production is already taking place at maximum capacity, and thus it is unlikely that coal output can be increased in time to meet a new surge in demand. Moreover, according to the White House's most optimistic forecasts, the proposals will cut demand for oil by some 2.3 million barrels a day, a figure which is well short of the predicted gap between supply and demand of three million barrels.

Thus, senior Administration officials are warning that it is likely that oil and gasoline rationing will have to be brought in before the winter has ended. Moreover, the problems will not disappear at least until the end of the 1970s when the Alaska pipeline will be bringing crude oil to the lower states. This winter is therefore likely to mark the end of an era of cheap, bountiful energy in the United States. 